\title{
Environmental Toxicology
}

\section{Metal Toxicity During Short-Term Sediment Resuspension and Redeposition in a Tropical Reservoir}

\author{
Eduardo Cimino Cervi, ${ }^{*}$ Michelle Hudson, Alison Rentschler, and G. Allen Burton Jr. \\ School for Environment \& Sustainability, University of Michigan, Ann Arbor, Michigan, USA
}

Abstract: Billings Complex is the largest water-storage reservoir in São Paulo, Brazil, and has been contaminated since the 1960s. Periodically, Billings sediments are subjected to currents causing resuspension and subsequent release of metals. A short-term (4-h) resuspension was simulated using sediment flux exposure chambers (SeFECs) to better understand the fate, bioavailability, and transport of iron ( $\mathrm{Fe})$, manganese $(\mathrm{Mn})$, and zinc $(\mathrm{Zn})$ during these events, as well as possible organism toxicity. Daphnia magna and Hyalella azteca were exposed during the 4-h resuspension, and were monitored after exposure for survival, growth, and reproduction. Resuspension rapidly deoxygenated the overlying water, decreased the $\mathrm{pH}$, and resulted in elevated dissolved Zn above the US Environmental Protection Agency's (2002) criteria for acute toxicity $\left(120 \mu \mathrm{g} \mathrm{L}^{-1}\right)$. However, $\mathrm{Zn}$ was scavenged (after $20 \mathrm{~h}$ ) from solution as new sorption sites formed. Dissolved $\mathrm{Mn}$ increased during and after resuspension, with maximum values at $20 \mathrm{~h}$ post exposure. An initial release of Fe occurred, likely associated with oxidation of acid-volatile sulfides, but decreased after $1 \mathrm{~h}$ of resuspension. The Fe decrease is likely due to precipitation as oxyhydroxides. No acute toxicity was observed during resuspension; however, mortality of $D$. magna and $H$. azteca occurred during the postexposure period. Daphnia magna also exhibited chronic toxicity, with decreased neonate production after exposure. This sublethal effect could lead to decreased zooplankton populations over a longer period in the reservoir. Environ Toxicol Chem 2019;38:1476-1485. @ 2019 SETAC

Keywords: Acid-volatile sulfide; Metal bioavailability; Sediment toxicity; Tropical ecotoxicology; Water quality criteria

\section{INTRODUCTION}

Metals are the most common and significant sediment pollutants (Hill et al. 2013), representing a threat to benthic communities because of their toxicity, persistent nature, and nonbiodegradability (Duman et al. 2007; Varol and Şen 2012). During advective processes, such as resuspension events arising from high flows, dredging, or vessel propeller wash, anoxic depositional sediments may be disturbed and released into overlying oxygenated waters (Burton and Johnston 2010). Changes in the physical and chemical environment (e.g., dissolved oxygen, redox, $\mathrm{pH}$, and oxidation of sulfides) may transform metals, directly affecting their mobility and bioavailability (Atkinson et al. 2007; Roberts 2012). The possible toxicity caused by such sediment resuspension, and its potential ecological impact on populations and communities of aquatic organisms, need to be explored (Carvalho et al. 1998; Fetters et al. 2016).

\footnotetext{
* Address correspondence to ecervi@umich.edu

Published online 24 April 2019 in Wiley Online Library

(wileyonlinelibrary.com).
}

DOI: $10.1002 /$ etc. 4434
Differences in climate and geochemistry between temperate and tropical aquatic ecosystems may also be of great importance when the fate of metals is compared (Silvério et al. 2005; Cervi et al. 2017; Wang et al. 2019). Metals can be in solution, sorbed, or coprecipitated with mineral surfaces and organic matter, but in anoxic sediments, iron sulfides may be the primary solid phases controlling metal availability (Charriau et al. 2011; Richards et al. 2018). When anoxic sediments are exposed to oxic conditions, acid volatile sulfide (AVS)-bound metals are released, followed by the rapid precipitation of dissolved iron ( $\mathrm{Fe}$ ) and manganese (Mn) as amorphous and poorly crystalline Fe/Mn oxyhydroxides (Caetano et al. 2003). Not all metals may be re-adsorbed, or they may not be tightly bound to solids, making them potentially toxic (Fetters et al. 2016).

Several studies have measured release of metals from sediments under simulated field conditions (Calmano et al. 1994; Carvalho et al. 1998; Cantwell et al. 2002; Caetano et al. 2003). Most recent investigations have used stirring and shaking methods to resuspend sediments (Hong et al. 2011; Durán et al. 2012; Pourabadehei and Mulligan 2016), with unrealistic suspension durations, or excessive levels of suspended particulate matter (SPM), ranging from 5 to $>1000 \mathrm{~g} \mathrm{~L}^{-1}$. 
Research on the toxicological effects of metals on aquatic organisms has mainly focused on temperate countries (Nguyen et al. 2011; De Jonge et al. 2012; Simpson and Spadaro 2016), so that tropical studies have used data from temperate species to assess toxicity (Carvalho et al. 1998; Rico et al. 2011). Several authors have hypothesized that extrapolation of temperate toxicity data for tropical assessments may place tropical ecosystems at undue risks, because differences in environmental conditions and species sensitivity are not normally considered (Castillo, et al. 1997; Lacher and Goldstein 1997; Kwok et al. 2007; Daam and Van den Brink, 2010).

There is also a paucity of studies on the influence of resuspension on toxicity to tropical species; however, the physicochemical processes of resuspension and metal release should be similar to those in temperature regions. Fetters et al. (2016) developed a sediment flux exposure chamber (SeFEC) for studying sediment resuspension. The SeFEC design allows a more representative metal exposure and associated toxicological effects under environmentally realistic conditions (0.2-1.0 $\mathrm{g} \mathrm{L}^{-1}$ of SPM). To assess resuspension effects on pelagic and epibenthic organisms, this exposure system was used to better understand the fate, bioavailability, and toxicity of metals from sediments in a contaminated tropical reservoir.

\section{MATERIALS AND METHODS}

\section{Site description}

Billings Complex $\left(23^{\circ} 42^{\prime} \mathrm{S}, 45^{\circ} 27^{\prime} \mathrm{W}\right)$ is the largest waterstorage reservoir in São Paulo, Brazil, covering an area of 127 $\mathrm{km}^{2}$, with an approximate volume of $1.2 \mathrm{~km}^{3}$ and mean depth of $10 \mathrm{~m}$ (Carvalho et al. 1998). Billings was built in the 1920s for hydropower generation and has been contaminated from sewage and industrial effluents since the 1960 s by the reversal of the Pinheiros River, a tributary of the Tietê River. The reservoir supplies approximately 1.8 million people, and is also used for fishing and swimming.

\section{Sediment and water characterization}

Initial laboratory and field screening assessments involving physical, chemical, and toxicological characterizations were conducted along 10 representative stations within Billings Reservoir (Figure 1).

Water quality parameters $(\mathrm{pH}$, redox potential, dissolved oxygen, conductivity, turbidity, and temperature) were measured at incremental depths (intervals of $1 \mathrm{~m}$ ) using a calibrated Horiba U-50 multiparameter water quality meter. Surface sediments were collected using a Petite Ponar grab sampler, and sediments were shipped at $-4{ }^{\circ} \mathrm{C}$ to the University of Michigan (Ann Arbor, MI, USA). All sediment analyses were performed within $7 \mathrm{~d}$ following collection.

Sediment samples were processed for AVS content and simultaneously extracted metals (SEMs; Simpson et al. 2005), dry weights, and loss on ignition (6-h combustion at $450{ }^{\circ} \mathrm{C}$ ) of organic carbon content. Subsamples were digested and analyzed for the metals cadmium (Cd), chromium (Cr), copper (Cu), $\mathrm{Fe}, \mathrm{Mn}$, nickel $(\mathrm{Ni})$, lead $(\mathrm{Pb})$, and zinc $(\mathrm{Zn})$. Organochlorine pesticides and semivolatile organic compounds were determined according to US Environmental Protection Agency (USEPA) methods 8270D (2007a) and 8081B (2007b), respectively.

Porewater was collected within the sediment bottles using a nitrogen-purged syringe attached to a Rhizon ${ }^{\circledR}$ sampler (0.22$\mu \mathrm{m}$ built-in filter; Rhizosphere). Overlying water was collected using 500-mL high-density polyethylene bottles and filtered through $0.45-\mu \mathrm{m}$ cellulose acetate $\left(\right.$ Minisart $^{\circledR}$; Sartorius). The

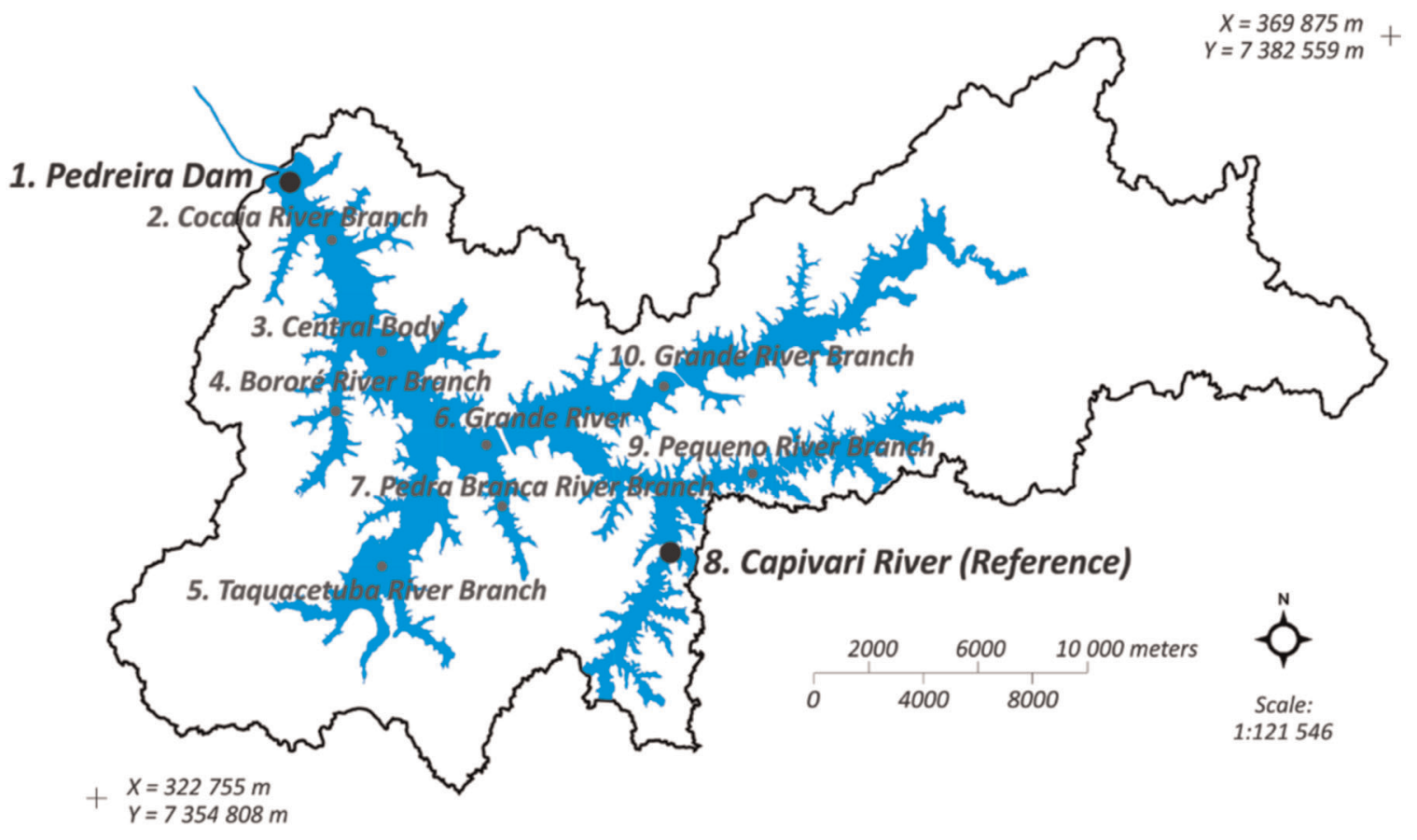

FIGURE 1: Initial screening sampling sites within Billings Reservoir with highlighted stations (in bold) chosen for short-term (4-h) resuspension tests. 
porewater and overlying water samples were acidified with concentrated $\mathrm{HNO}_{3}(2 \% \mathrm{v} / \mathrm{v} ;$ Merck) and analyzed for dissolved metals ( $\mathrm{Cd}, \mathrm{Cr}, \mathrm{Cu}, \mathrm{Fe}, \mathrm{Mn}, \mathrm{Ni}, \mathrm{Pb}$, vanadium, and $\mathrm{Zn}$ ) using an inductively coupled plasma-atomic emission spectrometer (Optima 8000 Series).

Based on initial screening results, 2 stations were chosen for resuspension tests-Pedreira Pumping Station and Capivari River-to represent the most contaminated sediments and a reference station, respectively (Table 1). Pedreira Pumping Station is highly impacted by industrial activities and urbanization and was selected based on its high SEM/AVS ratio and total metal concentrations, which exceeded the recommended probable effect concentration (PEC) or the severe effect level for $\mathrm{Cr}, \mathrm{Cu}, \mathrm{Fe}$, and $\mathrm{Zn}$. Criteria for reference site selection (the Capivari River) included similar water chemistry, but low metal and $\Sigma$ SEM/AVS content.

\section{Experimental design}

Short-term (4-h) sediment resuspension events were simulated using SeFECs modified from the chamber designs of others (Figure 2; Eggleston 2012; Fetters et al. 2016). The SeFEC was constructed from polycarbonate core tubes $(580 \mathrm{~mL})$ with polycarbonate end caps to minimize absorption and desorption of metals during resuspension. Pairs of chambers were connected by a recirculating system, with one chamber as a resuspension chamber and the other as an organism exposure chamber.

The exposure chamber contained an inner chamber $(9-\mathrm{cm}$ high $\times 2-c m$ i.d.) made of polycarbonate in which test organisms were held during resuspension and bedded experiments. The inner chamber had a screen $\left(26 \mathrm{~cm}^{2}\right)$ composed of nylon mesh (pore size of $250 \mathrm{~nm}$ ), allowing test organisms to be exposed to overlying water during resuspension (Fetters et al. 2016).

Sediment was resuspended using a motor powered by a 6-volt battery, which rotates a polycarbonate propeller, creating a vortex powerful enough to resuspend the surface layer sediment within the chamber. Two ports along the side of the chamber allow for sampling of both overlying water and porewater within settled sediment via Rhizon samplers (Figure 2).
The experimental design for resuspension tests was conducted according to Fetters et al. (2016). Sediment samples were gently homogenized before each experiment, avoiding excess contact with oxygen. Resuspension events were simulated by adding mixed sediment to the resuspension chamber to create a layer 3.5 to $4.0 \mathrm{~cm}$ thick. Particulate matter in the exposure chamber was kept in suspension by the use of a stir plate and Teflon-coated stir bar at the bottom of the exposure chamber at $150 \mathrm{rpm}$ to achieve approximately $1.0 \mathrm{~g} \mathrm{~L}^{-1}$ of SPM.

Comparison experiments using bedded sediment were conducted without induced shear stress but were otherwise identical. Water and suspended particles were recirculated between the resuspension and exposure chambers by a peristaltic pump at $30 \mathrm{rpm}$ through polyvinyl chloride tubing (3.2$\mathrm{mm}$ i.d.). Complete mixing of the water column between the chambers was achieved within $2 \mathrm{~h}$. All resuspension and bedded sediment experiments were $4 \mathrm{~h}$ in duration with 3 replicates. Physicochemical parameters $(\mathrm{pH}$, dissolved oxygen, conductivity, and temperature) were monitored in overlying water throughout the experiment at $0,15,30,60,120$, and 240 min. Dissolved $\mathrm{Fe}, \mathrm{Mn}$, and $\mathrm{Zn}$ concentrations were measured to determine the concentration of metals released.

After resuspension experiments, suspended sediments could settle over a 20-h period, after which redeposited sediments were subsampled (10-mm depth) to investigate the effects of resuspension on AVS/SEM concentrations. Initial screening AVS/SEM results (Table 1) were considered as preresuspension conditions. Dissolved $\mathrm{Fe}, \mathrm{Mn}$, and $\mathrm{Zn}$ were determined in both overlying water and porewater after the 20-h settling period to determine metal fluxes from the sediment.

\section{Short-term and postexposure toxicity testing}

Organisms cultured at the University of Michigan were exposed during short-term (4-h) resuspension tests and assessed after exposure to elucidate survival, growth, and reproduction endpoints (US Environmental Protection Agency 1991). Overlying water and sediment/porewater toxicity were assessed with Daphnia magna (10 neonates/replicate, $4 \mathrm{~d}$ old) and Hyalella azteca (10 organisms/replicate, $8 \mathrm{~d}$ old), respectively.

TABLE 1: Summary of physical and chemical properties of overlying water and sediment samples ( \pm standard deviation, $n=3$ ) from the Pedreira Pumping Station and Capivari River

\begin{tabular}{|c|c|c|c|c|c|}
\hline \multicolumn{3}{|c|}{ Surface water } & \multicolumn{3}{|c|}{ Surface sediment } \\
\hline Parameter & PED & REF & Parameter & PED & REF \\
\hline $\begin{array}{l}\text { Depth }(\mathrm{m}) \\
\mathrm{pH} \\
\text { ORP }(\mathrm{mV}) \\
\text { DO }\left(\mathrm{mg} \mathrm{L}^{-1}\right) \\
\text { Conductivity }\left(\mathrm{S} \mathrm{m}^{-1}\right) \\
\text { Turbidity }(\mathrm{NTU}) \\
\text { Temperature }\left({ }^{\circ} \mathrm{C}\right)\end{array}$ & $\begin{array}{c}10 \\
7.5 \pm 0.2 \\
66 \pm 32 \\
5.0 \pm 1.2 \\
184 \pm 11.9 \\
15.4 \pm 2.4 \\
24.6 \pm 0.2\end{array}$ & $\begin{array}{c}10 \\
8.4 \pm 0.4 \\
87 \pm 25 \\
5.4 \pm 2.0 \\
210 \pm 0.9 \\
13.1 \pm 1.1 \\
24.9 \pm 0.2\end{array}$ & $\begin{array}{c}\text { Texture } \\
\mathrm{pH} \\
\mathrm{E}_{\mathrm{H}}(\mathrm{mV}) \\
\text { LOI }(\% \mathrm{C}) \\
\text { Dry wt/wet wt (\%) } \\
\text { AVS ( } \mu \mathrm{mol} \mathrm{g}^{-1} \text { dry wt) } \\
\Sigma \mathrm{SEM} / \mathrm{AVS} \\
\Sigma \mathrm{SEM} / \mathrm{AVS} \\
{[\mathrm{SEM} / \mathrm{AVS}] / f_{\text {OC }}}\end{array}$ & $\begin{array}{l}\text { Silty clay } \\
6.6 \pm 0.1 \\
-103 \pm 7 \\
19.4 \pm 4.2 \\
14.5 \pm 0.5 \\
4.3 \pm 0.3 \\
6.1 \pm 0.4 \\
2.4 \pm 0.1 \\
77.2 \pm 5.9\end{array}$ & $\begin{array}{c}\text { Silty clay } \\
6.5 \pm 0.0 \\
-105 \pm 8 \\
17.7 \pm 3.4 \\
12.4 \pm 0.5 \\
4.3 \pm 0.3 \\
-2.2 \pm 0.6 \\
0.4 \pm 0.1 \\
-37.1 \pm 11.2\end{array}$ \\
\hline
\end{tabular}

PED = Pedreira Pumping Station; REF = Capivari River (reference); $\mathrm{pH}=$ potential of hydrogen; ORP = oxidation reduction potential; DO = dissolved oxygen; NTU = nephelometric turbidity unit; $\mathrm{E}_{\mathrm{H}}=$ redox potential; $\mathrm{LOI}=$ loss-on-ignition; Dry wt/wet wt = dry wt/wet wt ratio; $A V S=$ acid-volatile sulfide; $\mathrm{SEM}=$ simultaneously extracted metals; $f_{O C}=$ organic carbon fraction. 
Following short-term (4-h) resuspension, $H$. azteca were transferred into beakers containing $150 \mathrm{~mL}$ of culture water with a strip of unbleached paper towel and 3 preweighed, preconditioned $1-\mathrm{cm}$ diameter disks of red maple leaf (Acer rubrum). The $H$. azteca organisms were held for a 7-d recovery period to monitor survival and growth.

Daphnia magna were placed into beakers containing $25 \mathrm{~mL}$ of culture water and held for a 4-d recovery period to determine survival. At the start of postexposure monitoring and every other day, organisms were fed $0.25 \mathrm{~mL} \mathrm{~d}^{-1} /$ organism with Sel-Cero, a mixture of Raphidocelis subcapitata (green algae) and Cerophyl $\left(1.0 \times 10^{7}\right.$ algal cells $\left.\mathrm{mL}^{-1}\right)$. After a $4-\mathrm{d}$ recovery period, $D$. magna were kept in the beakers until they reached 3 brood cycles to assess reproduction, which was counted as total number of neonates produced per adult.

Three representative groups (10 organisms each) were collected to estimate initial mass on day 0 . Individual growth rate (IGR) was calculated according to Nedrich and Burton (2017) for both organisms as follows:

$$
I G R=\frac{\left[\frac{\sum\left(\text { mass }_{\text {org }}\right)_{\text {final }}}{n_{\text {org }}}=\frac{\sum\left(\text { mass }_{\text {org }}\right)_{\text {intial }}}{n_{\text {org }}}\right]}{\text { time }}
$$

where mass is in $\mu \mathrm{g}, \mathrm{n}$ is the number of organisms/replicate, and time is days.

Following short-term resuspension, chambers containing sediment received $100 \%$ culture water change and were used further for postexposure sediment toxicity tests. Daphnia magna and $H$. azteca were included together within the sediment chamber for 4 and $7 d$, respectively. These additional toxicity tests allowed for direct contact between test organisms and sediment. Hyalella azteca were not fed during exposure, to promote sediment grazing.

\section{Quality assurance/quality control}

All plastic and glassware used during the experiment process were new or soaked in $20 \%(\mathrm{v} / \mathrm{v})$ nitric acid for at least $24 \mathrm{~h}$ followed by 2 rinses with deionized water (prepared using a
Milli-Q $18 \mathrm{~m} \Omega \mathrm{cm}$ water). For quality control, all sediment samples were analyzed using a blank, control, and triplicates.

To confirm the viability of organisms used in both short-term and postexposure toxicity tests, D. magna and $H$. azteca controls consisted of 3 additional replicates each that were not exposed to either contaminated water or sediment. Organisms were held in $25 \mathrm{~mL}$ of clean water without food during the 4-h tests but were otherwise treated identically through postexposure monitoring procedures.

\section{Statistical analysis}

All statistical analyses were conducted in Excel ${ }^{\circledR}$ using the $\mathrm{XLSTAT}{ }^{\circledR}$ statistical software package. For significance testing, Shapiro's test for normality was used first to determine whether data were normal or skewed. Levene's test was used to determine whether variances were equal among treatments. Most data were not normally distributed due to natural heterogeneity of organisms' endpoints. For nonparametric data, Kruskal-Wallis tests were used for multiple variable comparisons, and the median or sign test was used for paired analysis (control vs Pedreira pumping station and Capivari River stations). For normally distributed variables, the equivalent one- or two-way analysis of variances were used for multivariate comparisons of normally distributed variables, followed by Tukey's honestly significant difference post hoc test when warranted.

\section{RESULTS}

\section{Overlying water}

Dissolved oxygen values during bedded and resuspension experiments are shown in Figure 3. For resuspended results, $T_{0}$ corresponds to the first minute of sampling after shear stress. Dissolved oxygen was significantly consumed during resuspension in samples from the Pedreira Pumping Station, decreasing from 8.7 to $1.3 \mathrm{mg} \mathrm{L}^{-1}$ within $2 \mathrm{~h}$. After redeposition ( $20 \mathrm{~h}$ ), dissolved oxygen increased slightly in Pedreira Pumping Station samples. The same trend was observed in Capivari River samples, with a significant decrease from 8.3 to $2.8 \mathrm{mg} \mathrm{L}^{-1}$ within $2 \mathrm{~h}$, and a

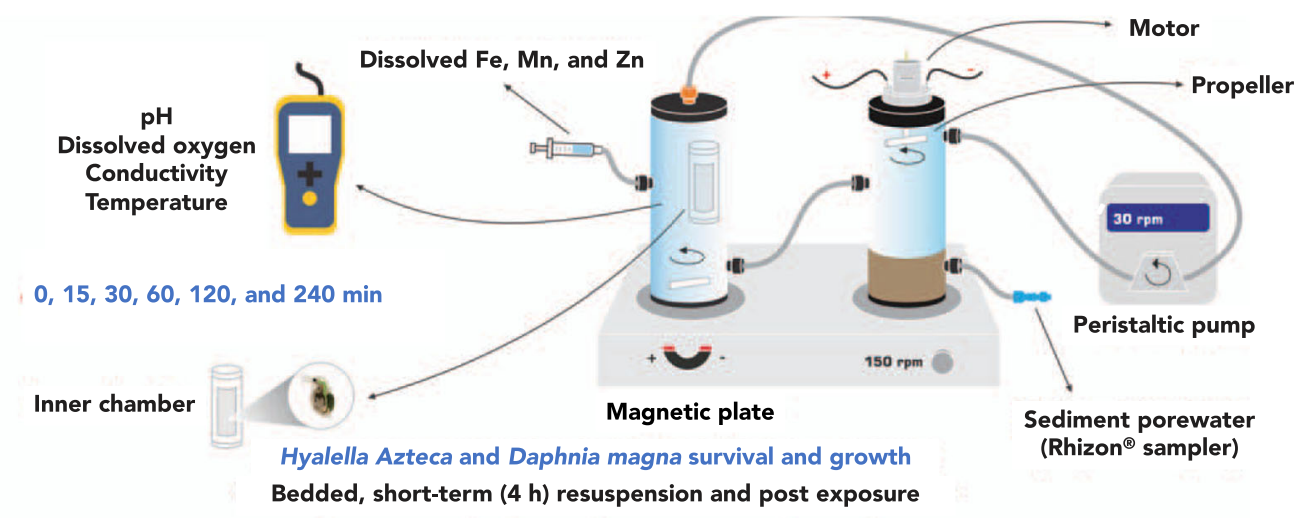

FIGURE 2: Concept model of the sediment flux exposure chamber setup for short-term (4-h) resuspension tests in the laboratory. 


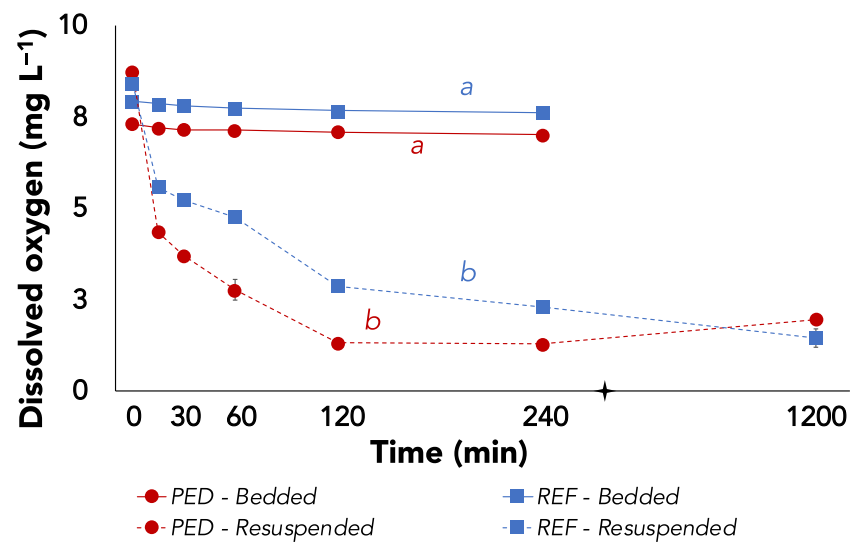

FIGURE 3: Dissolved oxygen concentrations in overlying water of bedded and short-term (4-h) resuspension tests in Pedreira Pumping Station (PED) and Capivari River (REF [reference]) samples ( \pm standard deviation, $n=3)$. Statistical significance $(p<0.01)$ is denoted with different letters.

further decrease to approximately $2 \mathrm{mg} \mathrm{L}^{-1}$ over $20 \mathrm{~h}$. In contrast, dissolved oxygen in the bedded experiments remained consistent, at approximately $7.5 \mathrm{mg} \mathrm{L}^{-1}$.

In bedded experiments, the $\mathrm{pH}$ remained constant at approximately 7 , although a sharp decrease of approximately 1 unit was observed within the first $15 \mathrm{~min}$ of resuspension (Figure 4). Consistent with $\mathrm{O}_{2}$ consumption, the $\mathrm{pH}$ continued to slowly decrease over $20 \mathrm{~h}$ in Pedreira Pumping Station samples to 5.9, whereas a slight increase was observed in Capivari River samples.

The temperature in bedded and resuspended conditions remained constant $(p<0.01)$. The overlying water temperature in bedded sediments averaged $23^{\circ} \mathrm{C}$, whereas resuspended overlying water remained at a temperature of $19^{\circ} \mathrm{C}$. This slight difference between bedded and resuspended conditions was due to sediment/overlying water mixing after resuspension, consequently decreasing the overlying water temperature.

Conductivity values in bedded experiments were consistent, at approximately 330 and $353 \mu \mathrm{S} \mathrm{cm}{ }^{-1}$ for Capivari River and

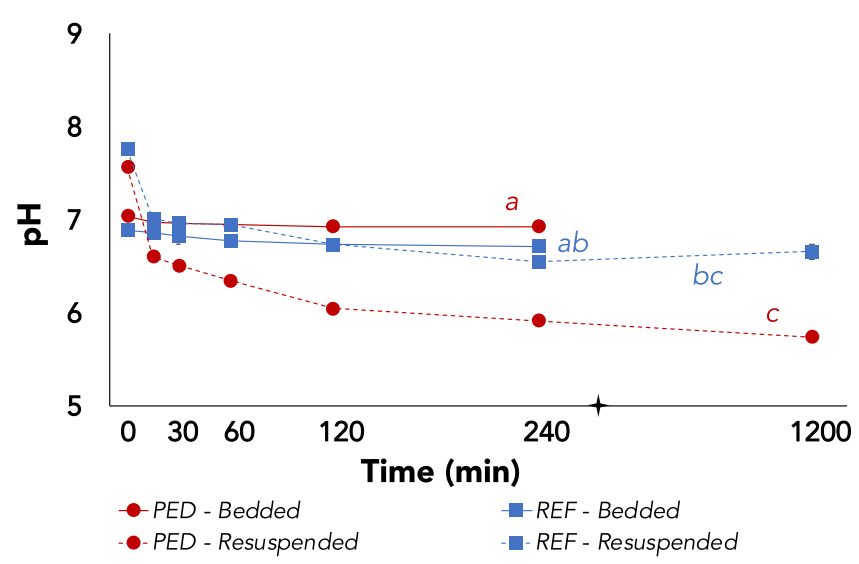

FIGURE 4: Overlying water $\mathrm{pH}$ of bedded and short-term (4-h) resuspension tests in Pedreira Pumping Station (PED) and Capivari River (REF [reference]) samples ( \pm standard deviation, $n=3$ ). Statistical significance $(p<0.01)$ is denoted with different letters.

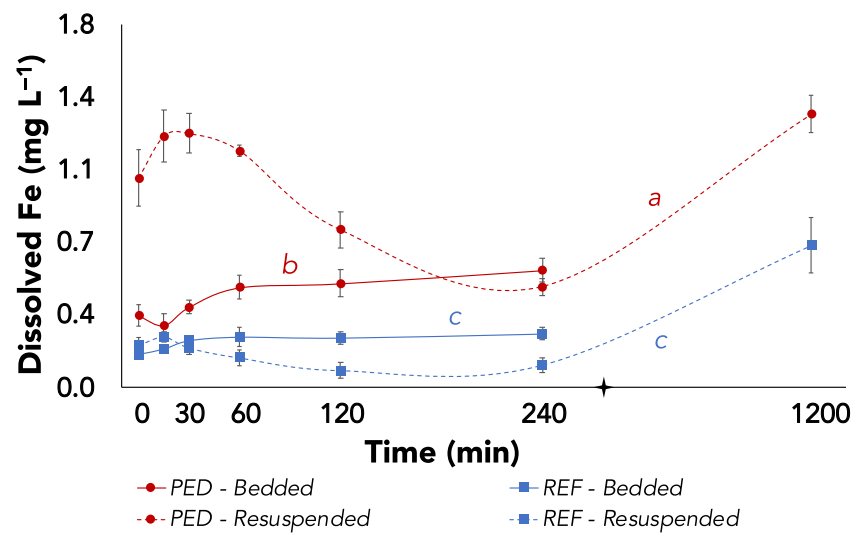

FIGURE 5: Dissolved iron (Fe) concentrations in overlying water of bedded and short-term (4-h) resuspension tests in Pedreira Pumping Station (PED) and Capivari River (REF [reference]) samples ( \pm standard deviation, $n=3)$. Statistical significance $(p<0.01)$ is denoted with different letters.

Pedreira Pumping Station samples, respectively. After resuspension, conductivity decreased from 356 to $339 \mu \mathrm{S} \mathrm{cm}{ }^{-1}$ within $2 \mathrm{~h}$ in Capivari River samples, and further increased to approximately $355 \mu \mathrm{S} \mathrm{cm}{ }^{-1}$ over $20 \mathrm{~h}$. Conductivity in Pedreira Pumping Station sediments increased from the beginning of short-term (4-h) resuspension $\left(361 \mu \mathrm{S} \mathrm{cm}{ }^{-1}\right)$ to their maximum value $\left(381 \mu \mathrm{S} \mathrm{cm}^{-1}\right)$ at $20 \mathrm{~h}$ post exposure.

\section{Dissolved metals}

Short-term (4-h) resuspension resulted in metal mobilization to overlying water that was sediment and metal specific. A significant release of $\mathrm{Fe}$ (Figure 5) occurred in Pedreira Pumping Station samples during the first $30 \mathrm{~min}$, but Fe decreased after $1 \mathrm{~h}$ of resuspension. In Pedreira Pumping Station samples, $\mathrm{Fe}^{2+}$ was almost totally oxidized after short-term resuspension, with concentrations similar to bedded conditions. The same trend was observed in Capivari River sediments.

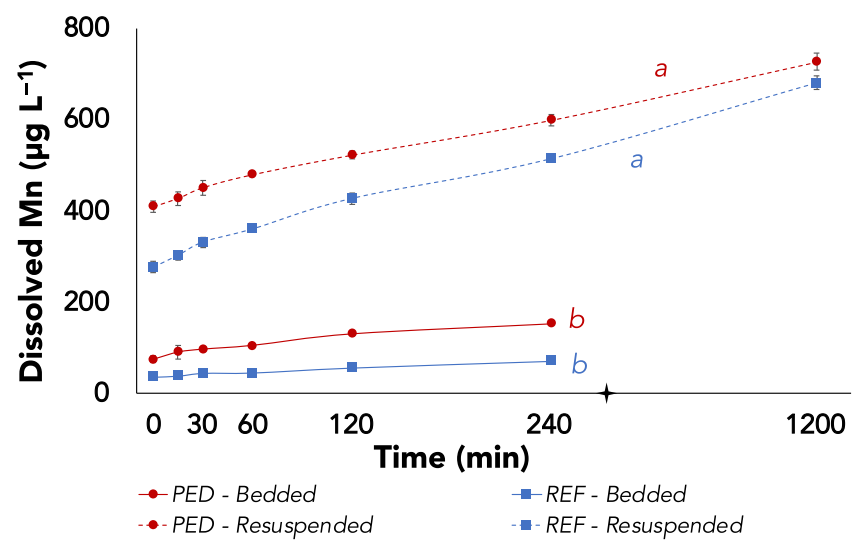

FIGURE 6: Dissolved manganese $(\mathrm{Mn})$ concentrations in overlying water of bedded and short-term (4-h) resuspension tests in Pedreira Pumping Station (PED) and Capivari River (REF [reference]) samples ( \pm standard deviation, $n=3)$. Statistical significance $(p<0.01)$ is denoted with different letters. 


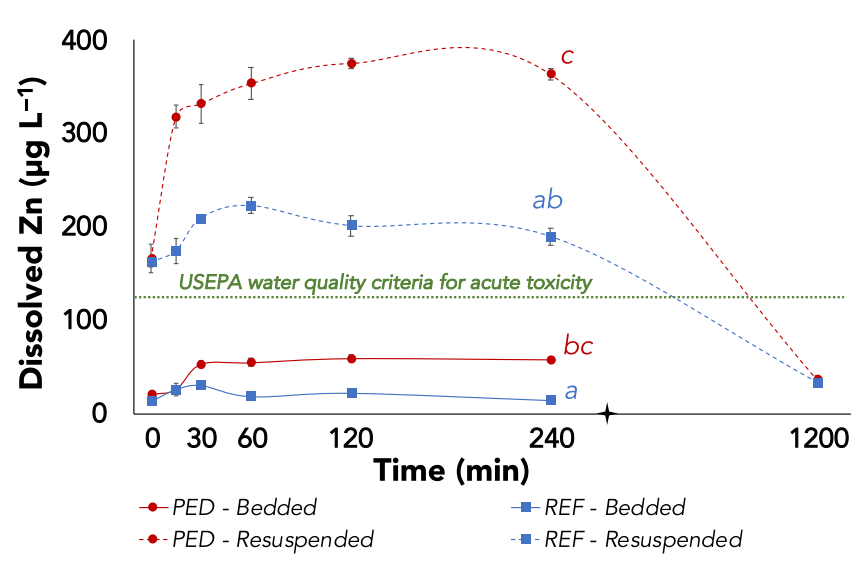

FIGURE 7: Dissolved zinc (Zn) concentrations in overlying water of bedded and short-term (4-h) resuspension tests in Pedreira Pumping Station (PED) and Capivari River (REF [reference]) samples ( \pm standard deviation, $n=3)$. Statistical significance $(p<0.01)$ is denoted with different letters. USEPA = US Environmental Protection Agency (2002).

Dissolved Fe concentrations at up to $1 \mathrm{~h}$ of resuspension were lower compared with bedded experiments.

After 20 h, Fe concentrations in the resuspended treatment increased in both Pedreira Pumping Station and Capivari River samples to approximately 1.3 and $0.6 \mathrm{mg} \mathrm{L}^{-1}$, respectively. Dissolved Fe released during the first hour of resuspension and at $20 \mathrm{~h}$ post exposure was above USEPA aquatic life criteria for chronic toxicity (1000 $\mathrm{g} \mathrm{L} \mathrm{L}^{-1}$; US Environmental Protection Agency 2002).

Dissolved Mn (Figure 6) remained below USEPA aquatic life criteria for chronic toxicity $\left(80 \mu \mathrm{g} \mathrm{L}^{-1}\right)$ during bedded conditions in both Capivari River and Pedreira Pumping Station samples $\left(35.0 \pm 3.4\right.$ and $73.9 \pm 7.1 \mathrm{mg} \mathrm{L}^{-1}$, respectively; US Environmental Protection Agency 2002). Unlike Fe, dissolved Mn increased ( $p<0.01$ ) from the beginning of short-term (4-h) resuspension up to its maximum values at $20 \mathrm{~h}$ post exposure in both Capivari River and Pedreira Pumping Station samples to $680.3 \pm 15.3$ and $726.4 \pm 17.9 \mathrm{mg} \mathrm{L}^{-1}$, respectively.

Zinc was immediately released to overlying water after resuspension, reaching concentrations 17-fold more than in bedded conditions for both Pedreira Pumping Station and Capivari River sediments (Figure 7). Trends for Zn were similar to those of Mn during short-term (4-h) resuspension and remained above the USEPA aquatic life criteria for acute toxicity (120 $\mu \mathrm{g} \mathrm{L} \mathrm{L}^{-1}$; US Environmental Protection Agency 2002). However, dissolved $\mathrm{Zn}$ decreased significantly in sediments from both sites at $20 \mathrm{~h}$ post exposure, decreasing to 33 and 36 $\mu \mathrm{g} \mathrm{L}^{-1}$ in Pedreira Pumping Station and Capivari River samples, respectively.

Porewater $\mathrm{Fe}$ and $\mathrm{Mn}$ decreased during resuspension in both sample types (Table 2). Release of $\mathrm{Fe}^{2+}$ to overlying water occurred mostly during the first $30 \mathrm{~min}$, providing a substrate for Fe oxide formation, whereas porewater was oxidized. Porewater $\mathrm{Mn}$ was significantly released during resuspension in Pedreira Pumping Station samples, decreasing from 3319 to $1477 \mathrm{mg} \mathrm{L}^{-1}$ over $20 \mathrm{~h}$. Lower Mn release was observed during resuspension in Capivari River samples, ranging between 1175 and $986 \mathrm{mg} \mathrm{L}^{-1}$ after $20 \mathrm{~h}$. Meanwhile, porewater $\mathrm{Zn}$ increased during resuspension. A rapid release was observed during initial shear stress, probably as a result of AVS oxidation, degradation of particulate organic matter, and/or diffusion/advection.

Both AVS and SEM were measured in both sediments under bedded and at $20 \mathrm{~h}$ post exposure (Table 3 ). When sulfide concentrations in sediments were compared, Pedreira Pumping Station and Capivari River samples were found to have the same AVS on average (4.33). However, the molar sum of SEM concentrations was higher than the molar concentration of AVS in Pedreira Pumping Station during bedded experiments and at $20 \mathrm{~h}$ post exposure. This is likely due to the higher Zn extracted by AVS/SEM in Pedreira Pumping Station ( 78\% of SEM values) compared with Capivari River samples ( $53 \%$ of SEM values).

When SEM/AVS is $>0$, there are more metals than the sulfide can bind, resulting in the likelihood of metals mobilizing to the dissolved phase, or in another metal-bound phase of the sediment. However, as normalized for organic carbon, SEM/AVS

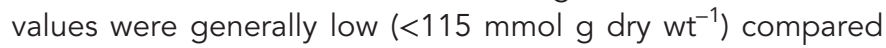
with reported toxicity thresholds for $\mathrm{Zn}$ of approximately 500 $\mathrm{mmol} \mathrm{g}$ dry weight ${ }^{-1}$ (Burton et al. 2006). According to the USEPA-recommended SEM/AVS model, these sediments would be considered "not toxic" (US Environmental Protection Agency 2016).

Acute toxicity was not observed during short-term (4-h) resuspension for both $D$. magna and $H$. azteca compared with laboratory controls ( $p<0.01$; Figure $8 \mathrm{~A}$ and $\mathrm{B}$, respectively). However, high mortality was observed when D. magna were held post exposure. Acute effects were significantly higher in Pedreira Pumping Station (organism survival of $16.6 \pm 5.7 \%$ ) compared with Capivari River (33.3 $\pm 5.7 \%$ survival) and control samples (93.3 $\pm 5.7 \%$ survival). Hyalella azteca survival was also affected post exposure in both Pedreira Pumping Station (53.3 $\pm 5.7 \%$ survival) and Capivari River samples (70 $\pm 0 \%$ survival).

TABLE 2: Porewater concentrations of dissolved Fe, Mn, and $\mathrm{Zn}( \pm$ standard deviation, $n=3$ ) during short-term (4-h) resuspension and at 20-h postexposure testing in samples from Pedreira Pumping Station and Capivari River sediments ${ }^{\mathrm{a}}$

\begin{tabular}{|c|c|c|c|c|c|c|}
\hline \multirow[b]{2}{*}{ Condition } & \multicolumn{2}{|c|}{$\mathrm{Fe}\left(\mathrm{mg} \mathrm{L}^{-1}\right)$} & \multicolumn{2}{|c|}{$M n\left(\mu g L^{-1}\right)$} & \multicolumn{2}{|c|}{$\mathrm{Zn}\left(\mu \mathrm{g} \mathrm{L}^{-1}\right)$} \\
\hline & PED & REF & PED & REF & PED & REF \\
\hline $\begin{array}{l}\text { Bedded } \\
20 \text { h post exposure }\end{array}$ & $\begin{array}{l}44 A \pm 9 \\
17 A \pm 2\end{array}$ & $\begin{array}{l}42 \mathrm{~B} \pm 7 \\
21 \mathrm{~B} \pm 3\end{array}$ & $\begin{array}{c}3319 A \pm 181 \\
1477 A \pm 84\end{array}$ & $\begin{array}{l}1175 B \pm 116 \\
986 B \pm 107\end{array}$ & $\begin{array}{l}118 \mathrm{~A} \pm 6 \\
206 \mathrm{~A} \pm 5\end{array}$ & $\begin{array}{l}16 \mathrm{~B} \pm 6 \\
82 \mathrm{~B} \pm 8\end{array}$ \\
\hline
\end{tabular}

${ }^{a}$ Different capital letters indicate statistically significant differences between groups $(p<0.01)$.

PED = Pedreira Pumping Station; REF = Capivari River (reference). 
TABLE 3: Acid-volatile sulfide and simultaneously extracted metals in Pedreira Pumping Station and Capivari River sediments $( \pm$ standard deviation, $n=3$ ) during bedded and 20 -h postexposure conditions

\begin{tabular}{|c|c|c|c|c|}
\hline \multirow{2}{*}{$\begin{array}{l}\text { Variable } \\
\text { ( } \mu \mathrm{mol} \mathrm{g}^{-1} \text { dry wt) }\end{array}$} & \multicolumn{2}{|c|}{ Bedded } & \multicolumn{2}{|c|}{20 h post exposure ${ }^{a}$} \\
\hline & REF & PED & REF & PED \\
\hline $\begin{array}{l}\text { AVS } \\
\sum \text { SEM/AVS } \\
\text { SEM/AVS } \\
{[S E M / A V S] / f_{O C}}\end{array}$ & $\begin{array}{c}4.33 \pm 0.37 \\
-2.23 \pm 0.68 \\
0.49 \pm 0.15 \\
-37.18 \pm 11.27\end{array}$ & $\begin{array}{c}4.33 \pm 0.33 \\
6.18 \pm 0.48 \\
2.43 \pm 0.11 \\
77.25 \pm 5.95\end{array}$ & $\begin{array}{c}3.29 \pm 0.52 \\
-0.64 \pm 0.26 \\
0.81 \pm 0.05 \\
-10.62 \pm 4.37\end{array}$ & $\begin{array}{c}3.22 \pm 0.36 \\
9.16 \pm 0.93 \\
3.88 \pm 0.61 \\
114.45 \pm 11.59\end{array}$ \\
\hline
\end{tabular}

a SEM/AVS analysis for 20-h postexposure conditions was determined in duplicate.

AVS = acid-volatile sulfide; SEM = simultaneously extracted metals; PED = Pedreira Pumping Station; REF = Capivari River (reference); $f_{\mathrm{OC}}=$ organic carbon fraction.

(A)

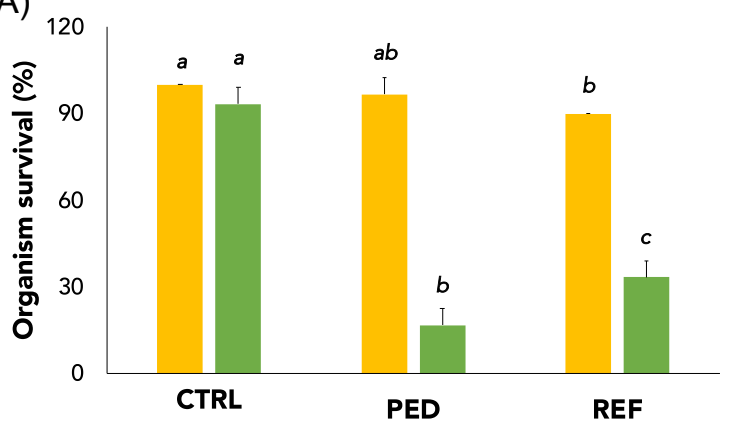

D. magna - $4 \mathrm{~h}$ resuspension $\quad$ D. magna - post exposure

(C)

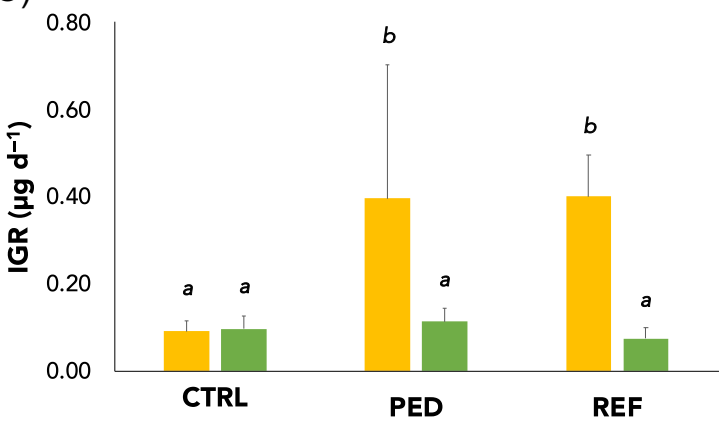

D. magna $-4 \mathrm{~h}$ resuspension
(B)

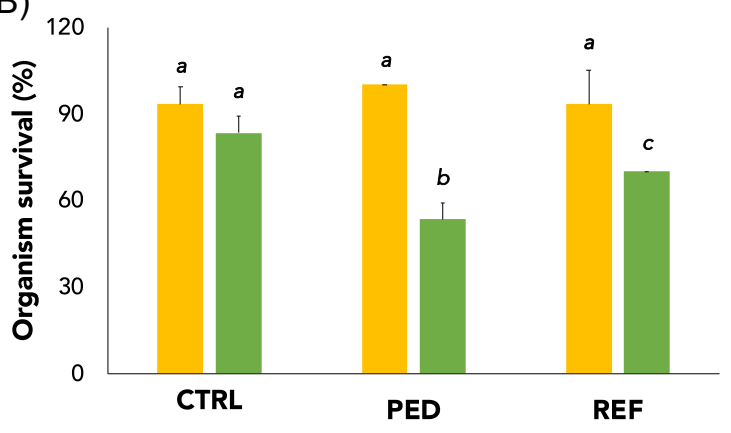

H. azteca $-4 \mathrm{~h}$ resuspension $\quad H$. azteca - post exposure

(D)

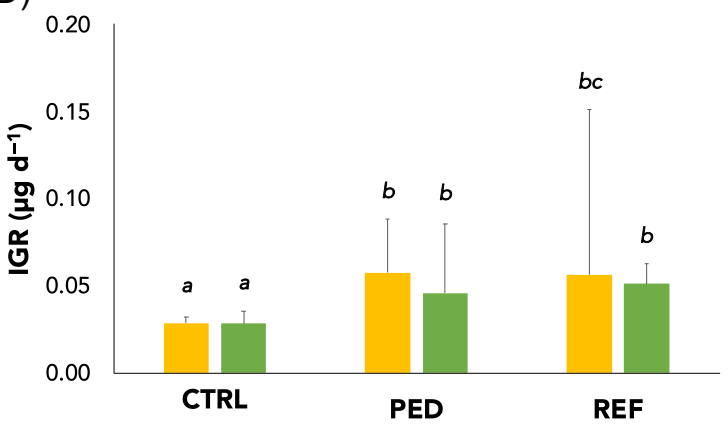

$\square$. azteca - 4 h resuspension $\quad$ H. azteca - post exposure

(E)

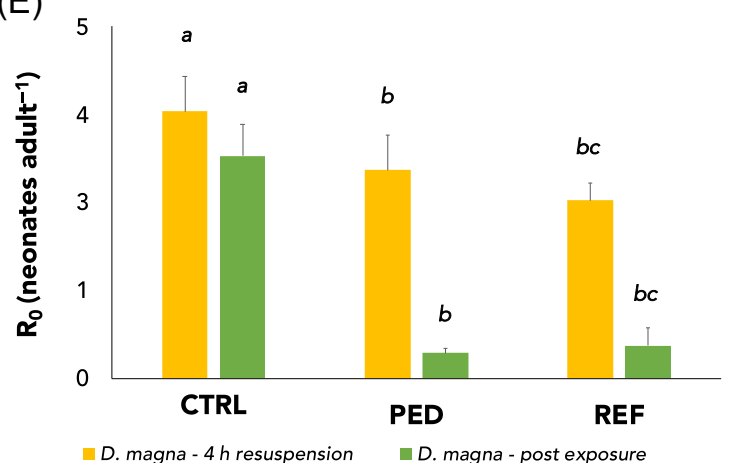

FIGURE 8: Organism survival, individual growth rate (IGR), and reproduction $\left(R_{0}\right)$ for Daphnia magna and Hyalella azteca after short-term (4-h) resuspension and postexposure testing in Pedreira Pumping Station (PED) and Capivari River (CAP [reference]) sediment compared with control (CTRL; \pm standard deviation, $n=3$ ), where $(\mathbf{A})$ is $D$. magna survival, (B) H. azteca survival, (C) D. magna IGR, (D) $H$. azteca IGR, and (E) D. magna $R_{0}$. Different letters indicate statistically significant differences between groups $(p<0.05)$. 
Short-term (4-h) resuspension did not affect the IGR of $D$. magna and $H$. azteca $(p<0.01)$. However, D. magna growth was significantly affected post exposure in Pedreira Pumping Station $\left(0.11 \pm 0.03 \mu \mathrm{g} \mathrm{d}^{-1}\right)$ and Capivari River samples $(0.07 \pm$ $\left.0.02 \mu \mathrm{g} \mathrm{d}^{-1}\right)$, with IGR values similar to those of water-only control $\left(0.09 \pm 0.02 \mu \mathrm{g} \mathrm{d}^{-1}\right)$. The H. azteca postexposure IGR was significantly higher in Pedreira Pumping Station (0.05 \pm $\left.0.00 \mu \mathrm{g} \mathrm{d}^{-1}\right)$ and Capivari River samples $\left(0.05 \pm 0.01 \mu \mathrm{g} \mathrm{d}^{-1}\right)$ compared with control $\left(0.02 \pm 0.00 \mu \mathrm{g} \mathrm{d}^{-1}\right)$, but was lower than in the bedded conditions.

Daphnia magna exhibited a slight decreased neonate production in Pedreira Pumping Station $\left(3.0 \pm 0.5\right.$ neonates adult $\left.{ }^{-1}\right)$ and Capivari River samples $\left(2.5 \pm 0.3\right.$ neonates adult $\left.{ }^{-1}\right)$ compared with control $\left(3.8 \pm 0.5\right.$ neonates adult $\left.{ }^{-1}\right)$ after short-term resuspension. However, D. magna reproduction was significantly affected post exposure in Capivari River and Pedreira Pumping Station samples $\left(0.5 \pm 0.3\right.$ and $0.4 \pm 0.1$ neonates adult $^{-1}$, respectively) compared with control ( $3.2 \pm 0.5$ neonates adult $\left.{ }^{-1}\right)$.

\section{DISCUSSION}

Dissolved oxygen significantly decreased in both sediment types within the first $2 \mathrm{~h}$. A similar trend was reported by Fetters et al. (2016), and this decline was attributed to $\mathrm{O}_{2}$ consumption via the formation of $\mathrm{Fe}$ oxyhydroxides and aerobic respiration. When anoxic contaminated sediments are disturbed, dissolved oxygen permeates the sediment, which drives the oxidation of sulfide, $\mathrm{Fe}$, and $\mathrm{Mn}$ complexes (Eggleton and Thomas 2004).

Sulfide oxidation implies that dissolved oxygen may also be depleted, as observed by others (Burton et al. 2006), which could lead to anoxic and/or hypoxic conditions that could be detrimental for organisms (Luther et al. 2004). Even though dissolved oxygen in Pedreira Pumping Station sediment was below the $2.5 \mathrm{mg} \mathrm{L}^{-1}$ recommended by the USEPA for toxicity testing (US Environmental Protection Agency 2002), we suggest that sulfide oxidation was not detrimental, because no acute toxicity was observed during short-term (4-h) resuspension. Oxygen consumption reflected a rapid oxidation of $\mathrm{Fe}$ on the surface of ferrous sulfide particles. The rate of $\mathrm{O}_{2}$ consumption slowed once $\mathrm{Fe}$ on the particle surfaces became oxidized.

Similar to dissolved oxygen, the $\mathrm{pH}$ in overlying water rapidly decreased within the first minutes of shear stress. The extent of $\mathrm{pH}$ reduction depends on the amount of sulfide in sediments and how much is oxidized (Roberts 2012). A change in chemical properties of the sediment contaminant causes mobilization and transfer of metals, mainly from sulfide-bound phases (Calmano et al. 1993). A more pronounced $\mathrm{pH}$ decrease was observed after resuspension of Pedreira Pumping Station sediment, likely due to higher concentrations of $\mathrm{Fe}$ and $\mathrm{Mn}$. The 1-unit lower $\mathrm{pH}$ in overlying water of Pedreira Pumping Station compared with $\mathrm{Ca}$ pivari River samples could be a possible explanation for the different release patterns of $\mathrm{Zn}$ via desorption from resuspended sediments.
A decrease in $\mathrm{pH}$ during resuspension may also be related to a lower buffering capacity of the Billings parent material. Parent material in temperate regions is often composed of primary minerals (carbonates and gypsum). which act as a buffer to mitigate acidity. On the other hand, in tropical regions such that of as Billings Reservoir, weathering is associated with intensive leaching and strongly oxidizing conditions, such that only hydrous oxides of aluminum, ferric $\mathrm{Fe}\left(\mathrm{Fe}^{3+}\right)$, and titanium persist (Sposito 2008).

The acid-producing capacity (APC) of a sediment/water system is counterbalanced by its acid-neutralization capacity. Quite often in tropical areas, sediments have a high APC due to the presence of lateritic soils. Tropical soils (such as oxisols) are mainly composed of weathered soils, and they have the highest average clay content, are the most acidic, and have the lowest organic carbon content, cation exchange capacity, and base saturation (Costa et al. 2004). In aquatic systems, the acidneutralization capacity of solids is always greater than that related to the dissolved phase. Using these assumptions, Calmano et al. (1993) proposed an index that could be used for sediment quality criteria: the effective acid-producing capacity $\left(A P C_{\text {eff }}\right)$, which is calculated from the oxidation of a known solid mass of sediments in a suspension volume, and the variation of suspension $\mathrm{pH}$ before and after oxidation.

For the present study, the calculated APC eff was $44.5 \mathrm{mmol}$ $\mathrm{H}^{+} \mathrm{kg}^{-1}$ (dry wt), which is 8.7 times greater than that observed by Calmano et al. (1993) for Elbe River (Czech Republic, Germany) anoxic sediment, which is also contaminated by metals. The high $A P C_{\text {eff }}$ of Billings sediments result in a significant release of metals to the aqueous phase and thus enhanced bioavailability.

When reduced $\mathrm{Fe}$ enters oxic waters, $\mathrm{Fe}^{2+}$ is rapidly oxidized. This chemistry creates an amorphous ferric hydroxide floc, which is rapidly oxidized to elemental sulfur or sulfate (Jones-Lee and Lee 2005). Freshly precipitated ferric hydroxide is an effective scavenger of numerous other metals (such as $\mathrm{Zn}$ ) in the water, an association that renders them unavailable. A similar phenomenon was described previously by Slotten and Reuter (1995), suggesting that resuspended Zn preferentially reabsorbs to newly formed colloidal or particulate ferric hydroxide in overlying water and becomes redeposited onto the sediment.

Colloidal or particulate ferric hydroxide in the water column can develop sufficient mass to settle and become part of the bedded sediments (Cantwell et al. 2002). Because these particles returned to the freshly redeposited sediment layer, we suggest that further oxidation occurred in the water column or in the aerobic sediment layer up to $20 \mathrm{~h}$, releasing labile species of Fe to the dissolved phase. The increase in dissolved $\mathrm{Mn}$ concentrations in overlying water at $20 \mathrm{~h}$ post exposure suggests that deposition of resuspended particles did not involve the scavenging of $\mathrm{Mn}$ from overlying water.

The kinetics of these reactions may also play an important role for trace element distributions during resuspension. Saulnier and Mucci (2000) observed that remobilized Fe was rapidly removed from the dissolved phase during the first hour of sediment resuspension, whereas the removal processes of $\mathrm{Mn}$ 
became predominant after 1 wk. In comparison, Gerringa (1990) sampled once a day during the first $3 \mathrm{~d}$ of experiment. He missed collecting the first hour of the resuspension and, thus, may have missed most of the Fe remobilization. Similarly, Caille et al. (2003) highlighted various readsorption rates for different metals.

The most dominant driver for $\mathrm{Zn}$ release is the oxidation of sediment sulfide (to sulfate), releasing $\mathrm{Zn}^{2+}$ (aq) from $\mathrm{ZnS}(\mathrm{s})$. Dissolution and oxidation of metal sulfides concurrently decreases $\mathrm{pH}$, thus increasing porewater $\mathrm{Zn}^{2+}$ via acidification of $\mathrm{Zn}$ hydroxides $\left(\mathrm{Zn}(\mathrm{OH})_{2}\right.$ or $\left.\mathrm{Zn}(\mathrm{OH})^{-1}\right)$ and carbonates $\left(\mathrm{ZnHCO}_{3}{ }^{-1}\right.$ or $\left.\mathrm{ZnCO}_{3}\right)$. However, solubilization of $\mathrm{Zn}$ from suspended particles was probably not from dissolution of $\mathrm{ZnS}$, given that metal sulfides can take more than $8 \mathrm{~h}$ to oxidize and that AVS concentrations were similar during bedding and after resuspension.

The high $\mathrm{Zn}$ concentration in Pedreira Pumping Station sediments during bedded conditions ( $77 \%$ of total SEM) indicated that $\mathrm{Zn}$ could be bioavailable for organism uptake and could potentially cause toxicity. In the environment, it is likely that metals such as $\mathrm{Cu}$ and $\mathrm{Ni}$ would be bound to the available AVS, and only a small portion of $\mathrm{Zn}$ would be bound. Simpson et al. (2000) observed that high proportions of $Z n$ in unmodified sediments may not be present as metal sulfides despite high AVS concentrations. Therefore, $\mathrm{Zn}$ would be the most likely metal to cause any observed toxicity.

The predominant means by which responses of organisms to chemical stressors are assessed and predicted by SeFECs. However, chemical characterization alone could underestimate the potential ecological implications of resuspended sediments in freshwater reservoirs. Due to the SeFEC inner chamber design, organisms are not exposed to the physical stress of the increase in total suspended solids that comes with naturally resuspended sediments. We believe that physical stress could be detrimental because it also influences the aquatic ecosystem in terms of water quality and biological responses.

The relevant exposures for the present study were through overlying water (zooplankton) and surficial sediments (benthos) and are reflected by toxicity testing of $D$. magna and $H$. azteca. Our results agree with those of previous studies showing that short resuspension periods are not likely to cause immediate toxicity but could cause chronic effects (Eggleton and Thomas 2004; Fetters et al. 2016). Although there was no significant acute toxicity to $D$. magna or $H$. azteca over the initial 4-h resuspension period, other long-term effects were noted such as increased mortality post exposure and decreased neonate production in both resuspended Pedreira Pumping Station and Capivari River sediments.

Aggregation of particles into flocs may occur relatively quickly (Roberts 2012). After resuspension, water column conditions were favorable to the formation of $\mathrm{Fe}$ and $\mathrm{Mn}$ oxyhydroxide flocs, which may have influenced lower dissolved Zn concentrations after redeposition. For epibenthic organisms such as $\mathrm{H}$. azteca, exposure pathways include ingestion of sediment and water. Ingestion of $\mathrm{Zn}$ can lead to cellular damage and displacement of dietary Fe, causing growth inhibition, reproductive issues, and mortality (Kubitz et al. 1996).
In addition, sediment porewater data reflect a migration of $\mathrm{Zn}$ from the overlying water into the sediments after resuspension. Among benthic organisms, some of those exposed to porewater and sensitive to $\mathrm{Zn}$ include chironomids, Ephemeroptera, and some crustaceans (including amphipods; Brinkman and Johnston 2008).

Fetters et al. (2016) observed that resuspension of $3 \mathrm{Zn}$ contaminated sediments resulted in minimal releases from suspended particles, likely because of scavenging on organic matter and $\mathrm{Fe}$ oxides formed during sediment interaction with oxic water. Only H. azteca was affected by $\mathrm{Zn}$ dissolution after sediment redeposition.

High dissolved $\mathrm{Fe}$ concentrations in the overlying water likely caused toxicity to D. magna. As described in the Dissolved metals section, $\mathrm{Fe}$ was continually released into the overlying water via sulfide oxidation, causing prolonged exposure. In addition, a rusty color was observed in D. magna bodies after postexposure tests, indicating Fe uptake. Again, relating this finding back to porewater data, there is a clear decrease in mobile $\mathrm{Fe}$ in sediments, suggesting release into the overlying water. Elevated metals in overlying water can lead to competitive exclusion of dietary calcium, causing hypocalcemia in D. magna, which decreases growth, affects organism movement, and decreases filtration rate (Muyssen et al. 2006).

\section{CONCLUSIONS}

Although sediment resuspensions are not a constant threat, they are common and may be an important stressor for organisms. Although there was no significant acute toxicity to $D$. magna or $\mathrm{H}$. azteca during a short-term resuspension period, long-term effects were noted. Adverse effects of resuspended contaminated sediments in hydrologically active systems, such as Billings Reservoir, should be considered during environmental management decision-making.

Data Accessibility—Please contact the corresponding author (ecervi@umich.edu) for any requests for access to data.

\section{REFERENCES}

Atkinson C, Jolley R, Simpson S. 2007. Effect of overlying water pH, dissolved oxygen, salinity and sediment disturbances on metal release and sequestration from metal contaminated marine sediments. Chemosphere 69:1428-1437.

Brinkman SF, Johnston WD. 2008. Acute toxicity of aqueous copper, cadmium, and zinc to the mayfly Rhithrogena hageni. Arch Environ Contam Toxicol 54:466-472.

Burton ED, Bush RT, Sullivan LA. 2006. Acid-volatile sulfide oxidation in coastal flood plain drains: Iron-sulfur cycling and effects on water quality. Environ Sci Technol 40:1217-1222.

Burton GA, Johnston EL. 2010. Assessing contaminated sediments in the context of multiple stressors. Environ Toxicol Chem 29:2625-2643.

Caetano M, Madureira M, Vale C. 2003. Metal remobilisation during resuspension of anoxic contaminated sediment: Short-term laboratory study. Water Air Soil Pollut 143:23-40.

Caille N, Tiffreau C, Leyval C, Morel JL. 2003. Solubility of metals in an anoxic sediment during prolonged aeration. Sci Total Environ 301:239-250. 
Calmano W, Hong J, Forstner U. 1993. Binding and mobilization of heavy metals in contaminated sediments affected by $\mathrm{pH}$ and redox potential. Water Sci Technol 28:223-235.

Calmano W, Forstner U, Hong J. 1994. Mobilization and scavenging of heavy metals following resuspension of anoxic sediments from the Elbe River'. In Alpers C, \& Blowes D eds, Environmental Geochemistry of Sulfide Oxidation. American Chemical Society, Washington, DC, USA. pp 298-321.

Cantwell MG, Burgess RM, Kester DR. 2002. Release and phase partitioning of metals from anoxic estuarine sediments during periods of simulated resuspension. Environ Sci Technol 36:5328-5334.

Carvalho PSM, Zanardi E, Buratini SV, Lamparelli MC, Martins MC. 1998. Oxidizing effect on metal remobilization and Daphnia similis toxicity from a Brazilian reservoir sediment suspension. Water Res 32:193-199.

Castillo LE, de la Cruz E, Ruepert C. 1997. Ecotoxicology and pesticides in tropical aquatic ecosystems of Central America. Environ Toxicol Chem 16:41-51.

Cervi EC, Fernandes F, Miranda RB, Mauad FF, Michalovicz L, Poleto C. 2017. Geochemical speciation and risk assessment of metals in sediments of the Lobo-Broa Reservoir, Brazil. Manag Environ Qual Int J 28:430-443.

Charriau A, Lesven L, Gao Y, Leermakers M, Baeyens W, Ouddane B, Billon G. 2011. Trace metal behavior in riverine sediments: Role of organic matter and sulfides. Appl Geochem 26:80-90.

Costa ACS, Bigham JM, Tormena CA, Pintro JC. 2004. Clay mineralogy and cation exchange capacity of Brazilian soils from water contents determined by thermal analysis. Thermochim Acta 413:73-79.

Daam MA, Van den Brink PJ. 2010. Implications of differences between temperate and tropical freshwater ecosystems for the ecological risk assessment of pesticides. Ecotoxicology 19:24-37.

De Jonge M, Teuchies J, Meire P, Blust R, Bervoets L. 2012. The impact of increased oxygen conditions on metal-contaminated sediments. Part I: Effects on redox status, sediment geochemistry and metal bioavailability. Water Res 46:2205-2214.

Duman F, Aksoy A, Demirezen D. 2007. Seasonal variability of heavy metals in surface sediment of Lake Sapanca, Turkey. Environ Monit Assess 133:277-283.

Durán I, Sánchez-Marín P, Beiras R. 2012. Dependence of Cu, Pb and Zn remobilization on physicochemical properties of marine sediments. Mar Environ Res 77:43-49.

Eggleston MR. 2012. Impact of sediment resuspension events on the availability of heavy metals in freshwater sediments. University of Michigan, Ann Arbor, MI, USA. Master's thesis

Eggleton J, Thomas KV. 2004. A review of factors affecting the release and bioavailability of contaminants during sediment disturbance events. Environ Int 30:973-980.

Fetters KJ, Costello DM, Hammerschmidt CR, Burton GA Jr. 2016. Toxicological effects of short-term resuspension of metal-contaminated freshwater and marine sediments. Environ Toxicol Chem 35:676-686.

Gerringa LJA. 1990. Aerobic degradation of organic matter and the mobility of $\mathrm{Cu}, \mathrm{Cd}, \mathrm{Pb}, \mathrm{Ni}, \mathrm{Zn}, \mathrm{Fe}$ and $\mathrm{Mn}$ in marine sediment slurries. Mar Chem 29:355-374

Hill NA, Simpson SL, Johnston EL. 2013. Beyond the bed: Effects of metal contamination on recruitment to bedded sediments and overlying substrata. Environ Pollut 173:182-191.

Hong YS, Kinney KA, Reible DD. 2011. Acid volatile sulfides oxidation and metals $(\mathrm{Mn}, \mathrm{Zn})$ release upon sediment resuspension: Laboratory experiment and model development. Environ Toxicol Chem 30:564-575.

Jones-Lee A, Lee G. 2005. Role of iron chemistry in controlling the release of pollutants from resuspended sediments. Remediation 16:33-41.

Kubitz JA, Besser JM, Giesy JP. 1996. A two-step experimental design for a sediment bioassay using growth of amphipod Hyalella azteca for the test endpoint. Environ Toxicol Chem 15:1783-1792.

Kwok KWH, Leung KMY, Lui GSG, Chu VKH, Lam PKS, Morritt D, Maltby L, Brock TCM, Van den Brink PJ, Warne MSJ, Crane M. 2007. Comparison of tropical and temperate freshwater species sensitivities to chemicals: Implications for deriving safe extrapolation factors. Integr Environ Assess Manag 3:49-67.

Lacher TE Jr, Goldstein MI. 1997. Tropical ecotoxicology: Status and needs. Environ Toxicol Chem 16:100-111.
Luther GW, Ma S, Trouwborst R, Glazer B, Blickley M, Scarborough RW, Mensinger MG. 2004. The roles of anoxia, $\mathrm{H}_{2} \mathrm{~S}$, and storm events in fish kills of dead-end canals of Delaware inland bays. Estuaries 27:551-560.

Muyssen BTA, De Schamphelaere KAC, Janssen CR. 2006. Mechanisms of chronic waterborne $\mathrm{Zn}$ toxicity in Daphnia magna. Aquat Toxicol 77:393-401.

Nedrich SM, Burton GA Jr. 2017. Sediment Zn-release during post-drought re-flooding: Assessing environmental risk to Hyalella azteca and Daphnia magna. Environ Pollut 230:1116-1124.

Nguyen LTH, Burton GA Jr, Schlekat CE, Janssen CR. 2011. Field measurement of nickel sediment toxicity: Role of acid volatile sulfide. Environ Toxicol Chem 30:162-172.

Pourabadehei M, Mulligan CN. 2016. Resuspension of sediment, a new approach for remediation of contaminated sediment. Environ Pollut 213:63-75.

Richards CM, van Puffelen JL, Pallud C. 2018. Effects of sediment resuspension on the oxidation of acid-volatile sulfides and release of metals (iron, manganese, zinc) in Pescadero Estuary (CA, USA). Environ Toxicol Chem 37:993-1006.

Rico A, Waichman AV, Geber-Corrêa R, van den Brink P. 2011. Effects of malathion and carbendazim on Amazonian freshwater organisms: Comparison of tropical and temperate species sensitivity distributions. Ecotoxicology 20:625-634.

Roberts DA. 2012. Causes and ecological effects of resuspended contaminated sediments (RCS) in marine environments. Environ Int 40:230-243.

Saulnier I, Mucci A. 2000. Trace metal remobilization following the resuspension of estuarine sediment: Saguenay Fjord, Canada. Appl Geochem 15:191-210.

Silvério PF, Fonseca AL, Botta-Paschoal CMR, Mozeto AA. 2005. Release, bioavailability and toxicity of metals in lacustrine sediments: A case study of reservoirs and lakes in Southeast Brazil. Aquat Ecosyst Health Manag 8:313-322.

Simpson SL, Spadaro DA. 2016. Bioavailability and chronic toxicity of metal sulfide minerals to benthic marine invertebrates: Implications for deep sea exploration, mining and tailings disposal. Environ Sci Technol 50:4061-4070.

Simpson SL, Apte SC, Batley GE. 2000. Effect of short-term resuspension events on the oxidation of cadmium, lead, and zinc sulfide phases in anoxic estuarine sediments. Environ Sci Technol 34:4533-4537.

Simpson SL, Batley GE, Chariton AA, Stauber JL, King CK, Chapman JC, Hyne RV, Gale SA, Roach AC, Maher WA. 2005. Handbook for Sediment Quality Assessment Commonwealth Scientific and Industrial Research Organisation, Bangor, NSW, Australia

Slotten DG, Reuter JE. 1995. Heavy metals in intact and resuspended sediments of a California reservoir, with emphasis on potential bioavailability of copper and zinc. Mar Freshw Res 46:257-265.

Sposito G. 2008. The Chemistry of Soils (2nd ed). Oxford University, New York, NY, USA

US Environmental Protection Agency. 1991. Compendium of ERT toxicity testing procedures. EPA 540/P-91/009. Technical Report. Washington, DC.

US Environmental Protection Agency. 2016. National recommended water quality criteria - Aquatic life criteria. [cited 2019 May 7]. Available at http:// www.epa.gov/wqc/national-recommended-water-quality-criteriaaquaticlife-criteria-table.

US Environmental Protection Agency. 2002. National recommended water quality criteria: 2002. EPA 822/R-02/047. Technical Report. Washington, DC.

US Environmental Protection Agency. 2007a. Method 8270D: Semivolatile organic compounds by gas chromatography/mass spectrometry (GC/ MS). Washington, DC.

US Environmental Protection Agency. 2007b. Method 8081B: Organochlorine pesticides by gas chromatography Washington, DC.

Varol M, Şen B. 2012. Assessment of nutrient and heavy metal contamination in surface water and sediments of the upper Tigris River, Turkey. Catena 92:1-10.

Wang Z, Knok KWH, Leung KMY. 2019. Comparison of temperate and tropical freshwater species' acute sensitivities to chemicals: An update. Integr Environ Assess Manag https://doi.org/10.1002/ieam.4122 